\title{
Decline in prevalence and asymmetric distribution of human $T$ cell lymphotropic virus 1 and 2 in blood donors, State of Minas Gerais, Brazil, 1993 to 2007
}

\author{
Declínio na prevalência e distribuição assimétrica do vírus linfotrópico de células T humanas \\ em doadores de sangue, Estado de Minas Gerais, Brasil, 1993 a 2007
}

Maria Regina Dias-Bastos ${ }^{1,2}$, Cláudia Di Lorenzo Oliveira ${ }^{3}$ and Anna Bárbara de Freitas Carneiro-Proietti ${ }^{2,4}$

\begin{abstract}
Introduction: Human T cell lymphotropic virus types 1 and 2 (HTLV-1/2) are endemic in Brazil and are screened for in transfusion services since 1993. This study evaluated the evolution of the prevalence of HTLV-1 and 2 in blood donors of the Hemominas Foundation from 1993 to 2007, and its geographical distribution in State of Minas Gerais, Brazil. Methods: The Hemominas Foundation is a centralized blood center in Minas Gerais, Brazil. The sources of data were the Hemominas Foundation Technical Bulletin and files from the centralized serological laboratory. Donors were tested in the period using enzyme linked immuno sorbent assays (ELISA), followed by Western blot, when repeatedly reactive. The data were analyzed by EPIINFO 6.2 and TABWIN 3.5 softwares. Results: The average seroprevalence in the period 1993-2007 was $\mathbf{0 . 1 \%}$. A steady decline occurred from $0.4 \%$ in 1993 to below $0.1 \%$ in 2002 and later, with a transient peak of $\mathbf{0 . 5} \%$ in 1994. HTLV reactivity distribution was asymmetrical in the state, with regions of higher prevalence, interspersed with low prevalence areas. Comparison of positive and negative donors verified that increasing age was proportional to virus positivity. Odds ratio for age ranged from 1.43 (30 to 39 years-old) to 3.09 (50 to 65 years-old). Women had a greater chance of being positive (OR-1.64), as previously described. Conclusions: Possible explanations for HTLV-1/2 prevalence decline are the exclusion of positive donors from the donor pool, an increase in repeat donors and ELISA test improvement, with reduction in the number of false positive results. Key-words: HTLV-1/2. Seroprevalence. Distribution. Blood donor. Minas Gerais. Brazil.
\end{abstract}

\begin{abstract}
RESUMO
Introdução: Os vírus linfotrópicos de células T humanas 1 e 2 (HTLV-1/2) são endêmicos no Brasil e são testados nos serviços de transfusão desde 1993. Este estudo avaliou a evolução da prevalência do HTLV-1 e 2 em doadores de sangue da Hemominas, de 1993 a 2007, bem como sua distribuição geográfica no Estado de Minas Gerais, Brasil. Métodos: A Hemominas é um serviço transfusional centralizado em Minas Gerais, Brasil. As fontes de dados foram o Boletim Técnico da Fundação Hemominas, e os dados informatizados do laboratório central de sorologia. Os doadores foram testados no período utilizando ensaio enzimático (ELISA), seguido de Western blot, para confirmação, se repetidamente reagentes. Os dados foram analisados utilizando EPIINFO 6.2 e TABWIN 3.5. Resultados: A prevalência media no período 1993-2007 foi de 0,1\%. Houve declínio contínuo de 0,4\% em 1993 para menos de 0,1\% de 2002 em diante, com um pico transitório de 0,5\% em 1994. A distribuição do HTLV foi assimétrica, com alternância de regiões de alta e baixa prevalências. A comparação entre doadores positivos e negativos mostrou que a idade aumenta a positividade para o vírus. A OR para idade variou de 1,43 ( 30 a 39 anos) a 3,09 ( 50 a 65 anos). As mulheres tiveram chance maior de ser positivas (OR-1,64), como descrito anteriormente. Conclusões: As possíveis explicações para o declínio do HTLV-1/2 foram a exclusão de doadores positivos, aumento nos doadores de repetição, e melhora nos testes de ELISA, com redução do número de testes falso positivos. Palavras-chaves: HTLV-1/2. Soroprevalência. Distribuição. Doador de sangue. Minas Gerais. Brasil.
\end{abstract}

1. Technical Management, Hemocenter of Belo Horizonte, Belo Horizonte, MG. 2. Interdisciplinary Research Group of HTLV, Hemominas Foundation, Belo Horizonte, MG. 3. Medicine School, Federal University of São João del Rei, Divinópolis, MG. 4. Presidency, Hemominas Foundation, Belo Horizonte, MG. Address to: Dra Anna Bárbara de Freitas Carneiro-Proietti. Fundação Hemominas. Rua Grão Pará 882, 30150-340 Belo Horizonte, MG.

Phone: 5531 3280-7490; Fax: 5531 3284-9579

e-mail: anna.proietti@hemominas.mg.gov.br

Received in $11 / 12 / 2009$

Accepted in 06/10/2010

\section{INTRODUCTION}

Human $\mathrm{T}$ cell lymphotropic virus type 1 and 2 (HTLV-1/2) were the first human retroviruses to be discovered. HTLV-1 is associated with adult T-cell leukemia (ATL), HTLV-associated myelopathy/ tropical spastic paraparesis (HAM/TSP), and HTLVassociated uveitis $(\mathrm{HAU})^{1}$. Phylogenetic studies suggest that HTLV-1 arrived in South America through fairly recent, multiple introductions, probably during African slavery. All South American countries have reported the presence of HTLV-1, but the prevalence varies greatly between and within countries and population groups. The reasons for HTLV-1 clustering remain unknown. Classically, a pattern of age and sex dependence occurs for HTLV-1 seroprevalence among blood donors, with prevalence higher in females and increasing steadily with age, similar to patterns observed in endemic areas of southern Japan and the Caribbean basin ${ }^{1}$.

Brazil is probably the country with the highest absolute number of HTLV-1/2 carriers in the world ${ }^{2}$; however, the prevalence varies between states, lower in the southern region (Florianopolis, in Santa Catarina, shows a prevalence of $0.04 \%$ ) and higher in the northern and northeastern regions: $0.9 \%$ in the State of Bahia, $1 \%$ in Maranhão and $0.9 \%$ in Pará. In a previous study, the State of Minas Gerais presented an intermediate prevalence of $0.7 \%^{2}$. This study showed a decline in Brazilian HTLV prevalence over a five year period, from a maximum of $0.7 \%$ in 1996 to $0.4 \%$ in 2000 .

In Brazil, HTLV-2 prevalence is higher in indigenous populations and among the Caiapós, prevalence was reported as higher than $25 \%^{3}$.

A study conducted in the State of Bahia in 2006 by Mota et al showed a prevalence of $0.5 \%$ in blood donors ${ }^{4}$. This prevalence was lower than that determined in 1993 by the same group (1.4\%), showing a significant decline over this period ${ }^{5}$.

The study of trends in prevalence of transmissible diseases provides a mechanism of evaluation of blood supply security and the effectiveness of blood donor deferral criteria, as well as of other measures of selection and testing ${ }^{6}$. 
The aim of this study was to analyze the evolution of prevalence of HTLV in blood donors from the Hemominas Foundation from 1993 to 2007, and to determine its geographic distribution and the demographic data for HTLV-1/2 positive blood donors in the period.

\section{METHODS}

\section{HTLV-1/2 testing}

The Hemominas Foundation has 21 blood collecting units all over the State of Minas Gerais and is responsible for $93 \%$ of the blood transfusion in this region. Since March 1993, it has screened blood donor candidates for HTLV-1/2 using an enzyme linked immuno sorbent assay (ELISA) method, while Western blot (WB) is used as a confirmatory test. The methods and kits used for the screening and confirmatory tests during this period are described in Table $\mathbf{1}$.

TABLE 1 - HTLV-1/2 screening and confirmatory tests for blood donors, Hemominas Foundation, State of Minas Gerais, Brazil, 1993-2007.

\begin{tabular}{|c|c|c|}
\hline Period & ELISA & Western blot \\
\hline 1993 to 1995 & 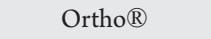 & Cambridge Biotech $\mathbb{R}$ \\
\hline \multirow[t]{2}{*}{1996} & Organon ${ }^{\circledR}$ & Cambridge Biotech ${ }^{\circledR}$ \\
\hline & & Genelabs Diagnostics 2.4® \\
\hline \multirow[t]{2}{*}{1997} & Ortho $®$ & Cambridge Biotech ${ }^{\circledR}$ \\
\hline & & Genelabs Diagnostics 2.4® \\
\hline \multirow[t]{2}{*}{1998} & 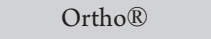 & Cambridge Biotech $\mathbb{R}$ \\
\hline & & Genelabs Diagnostics 2.4® \\
\hline 1999 to May 2005 & Ortho $®$ & Genelabs Diagnostics 2.4® \\
\hline June 2005 to June 2006 & Abbott $®$ (Murex) & Genelabs Diagnostics 2.4® \\
\hline July 2006 to July 2008 & Ortho ${ }^{\circledR}$ & Genelabs Diagnostics 2.4® \\
\hline
\end{tabular}

Blood donors with positive or indeterminate results are invited by letter to draw a second sample. In case of a no show, a second letter is sent. This action is repeated for a third time, if necessary. At this point, if there is no reply from the donor, the case is reported to the sanitary authorities (VISA-MG, the State Sanitary Agency). In cases of second sample collection, HTLV ELISA is performed twice and WB is performed when the ELISAs are repeatedly reactive. Seropositive donors are invited to enter a cohort study of HTLV carriers that has been established since 1997 by the HTLV Interdisciplinary Research Group (GIPH) ${ }^{3}$.

\section{Data collection}

Between 1993 and 2007, the data of blood donors from all units of the Hemominas Foundation in the state was routinely collected and published monthly, as an internal technical bulletin. Before 1999, the data was divided into two main categories, i.e., the metropolitan region and regional units. It was only after 2000 that data collection changed to a regional basis, with each unit individualized. As a consequence, it was possible to evaluate data from each regional unit only after 2000 .

The demographic variables analyzed were sex, age, skin color (as surrogate for race), and city of residence. The variable skin color was defined as white, black, or mixed by the member of staff attending the registration, until the year 2007. After this year, the skin color was self-defined by the donor.

\section{Geographical analysis}

For geographic distribution evaluation, the prevalence of reactive first time donors from 19 units of the Hemominas Foundation, in the period of 2003 to 2007, was used. This distribution was assessed by TABWIN 32 version 3.5 software. The 19 units of the Hemominas Foundation are codified as: Além Paraíba (ALP), Betim (BET), Diamantina (DIA), Divinópolis (DIV), Governador Valadares (GOV), Hemocentro Belo Horizonte (HBH), Hospital Júlia Kubitcheck-BH (HJK), Ituiutaba (ITU), Juiz de Fora (JFO), Manhuaçu (MCU), Montes Claros (MOC), Pouso Alegre (PAL), Passos (PAS), Patos de Minas (PMI), Ponte Nova (PNO), São João del Rei (SJR), Sete Lagoas (SLA), Uberlândia (UDI) and Uberaba (URA).

\section{Statistical analysis}

The odds ratio (OR) and 95\% confidence interval (CI) were used to evaluate associations between the variables and HTLV infection. Statistical calculations were performed using the software EPIINFO, version 6.2.

\section{RESULTS}

\section{Blood donors}

In the period from 1993 to $2007,3,249,944$ donors considered clinically apt were tested by an ELISA method and 4,658 (0.1\%) donors had a reactive test. From a reactivity of 0.40 in 1993 and a maximum peak of reactivity of $0.48 \%$ in 1994 , a decline in the reactivity was observed up to 2002 , stabilizing since then under $0.1 \%$, as shown in Figure 1.

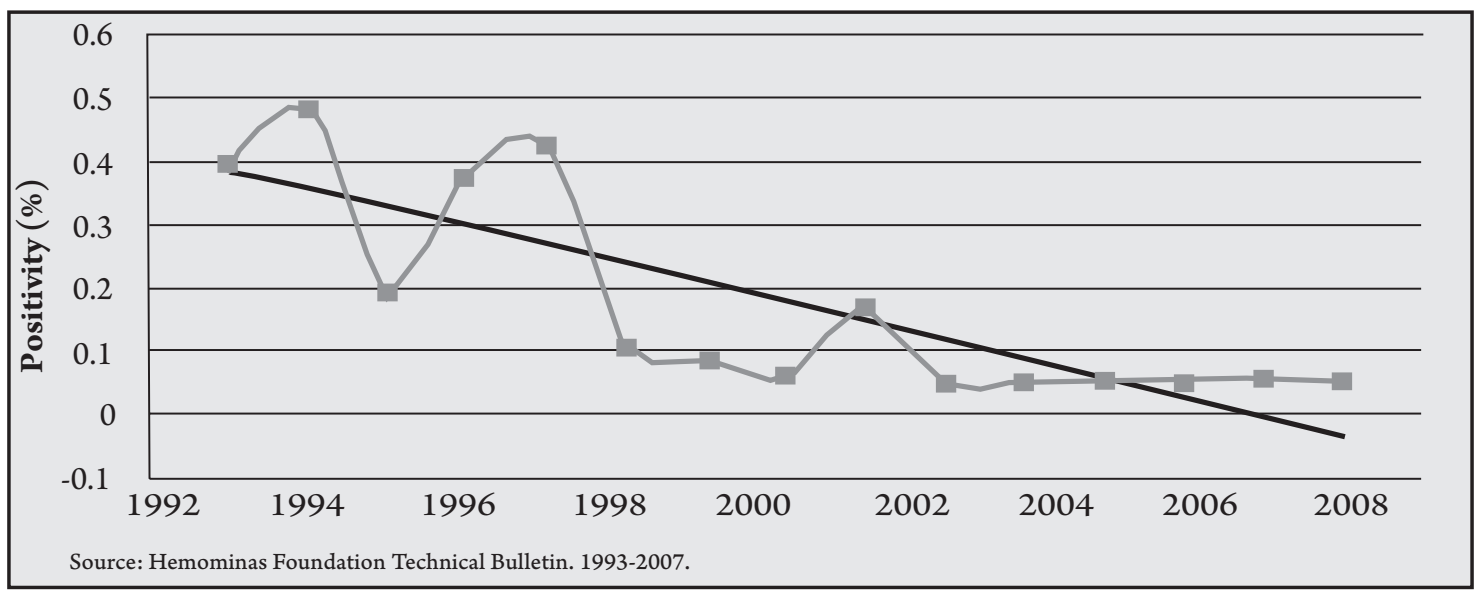

FIGURE 1- Trend of HTLV-1/2 screening test positivity in blood donors. Hemominas Foundation, State of Minas Gerais, Brazil, $1993-2007$. 
Among the 4,658 donors with an HTLV-1/2 reactive screening test in the period from 1993 to 2007 , only $46.3 \%$ returned for a second sample collection. The return rate was lower in 1996 (only 28\%) and higher in 2005 (71.9\%). In donors who had a WB test performed in the period from 1993 to $2007,42 \%$ were negative, $23 \%$ indeterminate and $34.3 \%$ positive, with variations in the different years.

Considering the age range and comparing donors with positive $\mathrm{WB}$, i.e. confirmed positive, with those with negative serology, increasing age is proportional to HTLV positivity (Table 2). Odds ratios ranged from 1.43, in the 30-39 years age group, to 3.09, in the 50-65 years age group. As for sex, comparing donors with positive WB with those with negative tests, women showed a higher probability of being positive than men $(\mathrm{OR}=1.64)$. For skin color, as a surrogate marker for race, donors with mixed (mulattos) and black skin showed a higher probability of being positive than donors with white skin (OR of 1.28 and 1.87, respectively).

\section{Geographic distribution of reactive first time blood donors}

The regional prevalences of reactivity in the screening test in first time blood donors in the period from 2003 to 2007 were heterogeneous (Table 3 and Figure 2) and were higher in Sete Lagoas and the Greater Belo Horizonte metropolitan area (Sete Lagoas 269.5/100,000 donations and HBH 264.9/100,000 donations), lower in the southern region (São João del Rei 100.9/100,000 donations, Ponte Nova 105/100,000 donations and Pouso Alegre $114.5 / 100,000$ donations), and intermediate in other regions.

TABLE 2 - Demographic risk factors associated with HTLV WB positivity in donors reactive in the screening test (EIA). Hemominas Foundation, State of Minas Gerais. Brazil, 1993-2007.

\begin{tabular}{|c|c|c|c|c|c|c|c|c|}
\hline \multirow[b]{3}{*}{ Variables } & & \multicolumn{4}{|c|}{ Western blot } & \multirow[b]{3}{*}{ Odds ratio } & \multirow[b]{3}{*}{ Confidence interval } & \multirow[b]{3}{*}{$\mathrm{p}$} \\
\hline & & \multicolumn{2}{|c|}{ positive } & \multicolumn{2}{|c|}{ negative } & & & \\
\hline & & $\mathrm{n}$ & $\%$ & $\mathrm{n}$ & $\%$ & & & \\
\hline \multirow[t]{4}{*}{ Age range (years) } & $18-29$ & 276 & 37.5 & 487 & 52.8 & 1 & & \\
\hline & $30-39$ & 214 & 29.0 & 263 & 28.5 & 1.43 & $\mathrm{CI}(1.14-1.81)$ & 0.0024 \\
\hline & $40-49$ & 168 & 22.8 & 128 & 13.9 & 2.31 & $\mathrm{CI}(1.76-3.04)$ & $<0.0001$ \\
\hline & $50-65$ & 79 & 10.7 & 45 & 4.9 & 3.09 & CI (2.08-4.59) & $<0.0001$ \\
\hline \multirow[t]{2}{*}{ Sex } & male & 438 & 59.4 & 652 & 70.6 & 1 & & \\
\hline & female & 299 & 40.6 & 271 & 29.4 & 1.64 & CI (1.34-2.01) & $<0.0001$ \\
\hline \multirow[t]{3}{*}{ Skin color* } & white & 202 & 28.1 & 307 & 33.9 & 1 & & \\
\hline & mixed & 475 & 66.1 & 564 & 62.3 & 1.28 & CI (1.03-1.58) & 0.0247 \\
\hline & black & 42 & 5.8 & 34 & 3.8 & 1.87 & CI (1.15- 3.05) & 0.0110 \\
\hline Total & & 737 & & 923 & & & & \\
\hline
\end{tabular}

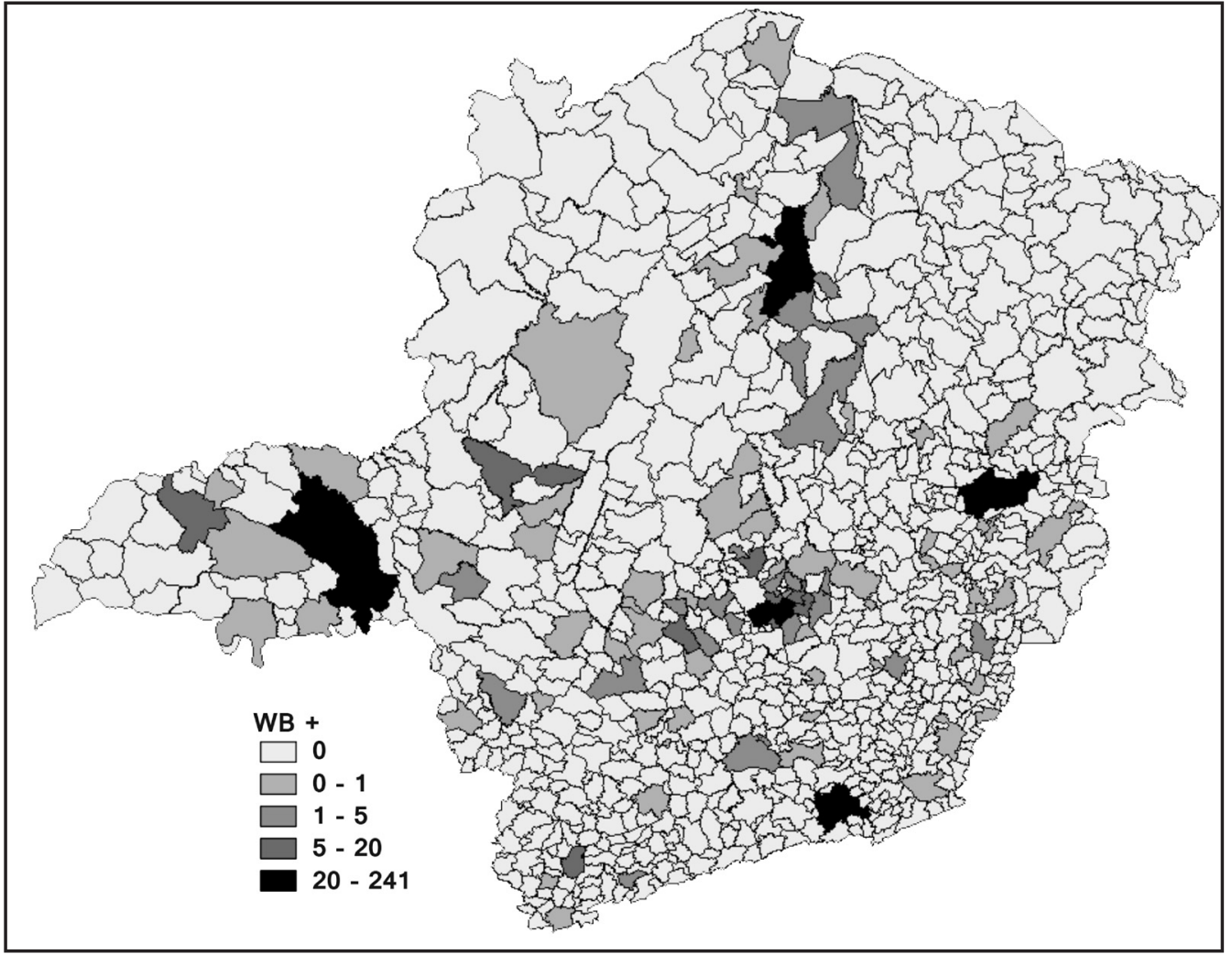

FIGURE 2 - Geographical distribution by city of donation of reactive HTLV-1/2 by first-time donors, Hemominas Foundation, State of Minas Gerais, Brazil, 2003-2007. 
TABLE 3 - HTLV-1/2 prevalence in every 100,000 first time donations screening test at each Hemominas Foundation unit from 2003 to 2007.

\begin{tabular}{|c|c|c|c|}
\hline Regional unit & $\begin{array}{l}\text { Seropositive first } \\
\text { time donors (n) }\end{array}$ & Prevalence $/ 10^{5}$ & $(95 \% \mathrm{CI})$ \\
\hline Betim & 33 & 196 & $(139.9-275.2)$ \\
\hline Diamantina & 9 & 203 & $(108.2-384.9)$ \\
\hline Divinópolis & 26 & 120.7 & $(82.6-176.8)$ \\
\hline Governador Valadares & 39 & 201.4 & $(147.6-275.2)$ \\
\hline Hemocentro de Belo Horizonte & 246 & 264.9 & $(233.9-300.1)$ \\
\hline Hospital Júlia Kubitscheck & 44 & 202.5 & $(151.1-271.7)$ \\
\hline Ituiutaba & 8 & 197.9 & $(101.8-389.5)$ \\
\hline Juiz de Fora & 67 & 188.2 & $(148.3-238.9)$ \\
\hline Manhuaçu & 18 & 237.2 & $(150.8-374.5)$ \\
\hline Montes Claros & 50 & 234.7 & $(178.3-309.3)$ \\
\hline Pouso Alegre & 21 & 114.5 & $(75.2-174.9)$ \\
\hline Passos & 10 & 127.2 & $(69.9-233.8)$ \\
\hline Patos de Minas & 14 & 171.9 & $(103.1-288.3)$ \\
\hline Ponte Nova & 10 & 105 & $(57.7-193)$ \\
\hline São João Del Rei & 7 & 100.9 & $(49.8-207.7)$ \\
\hline Sete Lagoas & 24 & 269.5 & $(181.7-400.7)$ \\
\hline Uberlândia & 31 & 140.8 & $(99.4-199.8)$ \\
\hline Uberaba & 32 & 206.7 & $(146.7-291.6)$ \\
\hline Total & 691 & 198.9 & $(184.6-214.3)$ \\
\hline
\end{tabular}

\section{DISCUSSION}

Since 1993, when the Hemominas Foundation began screening blood donors for HTLV-1/2, the reactivity pattern has changed, showing a clear decline. From 2002 onward, seroprevalence has been under $0.1 \%$. In the United States, a Red Cross study showed a $0.4 \%$ positivity rate in the screening test of blood donors. Later studies showed lower positivity rates, varying from 0.01 to $0.03 \%$ in the Unites States ${ }^{8}$, positivity of $0.0017 \%$ in Canada ${ }^{9}$, of $0.002 \%$ in Norway ${ }^{10}$ and of $0.0056 \%$ in Greece ${ }^{11}$.

Possible explanations for the prevalence reduction are the exclusion of positive donors from the donor population at the beginning of testing, the improvement of ELISA test quality, with reduction in the number of false positive tests and higher commitment of repeat donors. A way of preventing an artificial reduction in prevalence in the donor population resulting from the increased number of repeat donors is to calculate the prevalence based only on first time donors, which is also useful for incidence and residual risk studies ${ }^{6}$.

The variations verified in the $\mathrm{WB}$ test indeterminate results can be partially explained by the different methods used during the period, by the possibility of cross reaction with new varieties of $\mathrm{HTLV}^{12}$, cross reaction with other viruses, such as the dengue virus ${ }^{13}$, chickenpox and herpes simplex ${ }^{14}$, severe acute respiratory syndrome virus (SARS $)^{15}$, malaria ${ }^{14,16}$ and by the presence of individuals in the initial stages of HTLV infection ${ }^{17}$.

The low return rate for the confirmatory test (46.3\%) demonstrated the need to reevaluate the current methods of dealing with reactive donors in the blood center. The current practice of sending three consecutive letters could be improved by telephonic contact, for example. Another improvement could be the use of WB testing in the first ELISA positive screening sample. The low return rate was not uniform, with some cities reporting a higher number of positive cases that did not return for the WB. This could be explained by the differences in distance between the donor residence and the blood bank, making it more difficult to return to draw a second sample.

According to the 2006 census of the National Research per Sample of Domiciles (Pesquisa Nacional por Amostra de Domicilios, PNAD $)^{18}$, the racial distribution, based on skin color assessment in the State of Minas Gerais, for its 19.5 million inhabitants population was: $46.2 \%$ whites, $8.4 \%$ blacks, $45 \%$ mixed (mulatto) and $0.3 \%$ of other origin (Indigenous and Asian). In the blood donor population, a higher percentage of the mixed (mulatto) (62.3\%) than the white population $(33.9 \%)$ was verified. These differences may be a result of different skin color criteria. In the census, skin color is self-declared and in the Hemominas Foundation data, up to 2007 , it was defined by the registration staff. From 2008 on, the Hemominas Foundation adopted the same criterion as the census for skin color definition. Concerning the analyses using skin color as surrogate for race, although we identified a similar pattern to that reported in the literature ${ }^{7}$, the present findings must be evaluated with caution due to the absence of data for 36 donors. Although the majority of apt donors are males, women showed a greater probability of being WB positive, as previously described ${ }^{7}$.

The asymmetric distribution of HTLV-1/2 prevalence in blood donors in different regions of the State of Minas Gerais is similar to findings reported by Catalan-Soares ${ }^{2}$ in different Brazilian states and is classically referred to as the tendency for clustering of this infection, as observed in other areas of the world, such as Japan and the Caribbean ${ }^{1,19,20}$. The study by Catalan-Soares ${ }^{2}$ verified lower HTLV reactivity in the southern region of Brazil, intermediate positivity in the State of Minas Gerais (southeastern region of Brazil) and higher rates in the States of Pernambuco, Bahia and Maranhão, all in the northeastern region of Brazil ${ }^{19}$. In this study, higher reactivity was verified in the screening test for HTLV in the metropolitan area of Belo Horizonte and a lower prevalence in the south of the state.

One limitation of the study was that the data analyzed was derived from a secondary administrative database, not a database created for research purposes. Some data collecting criteria changed over the period analyzed and the return rate for a confirmatory test was lower than expected.

A clear reduction in total HTLV prevalence in blood donors in the period analyzed was determined that can be explained by a reduction in prevalence in the general population, by donor selection caused by the exclusion of positive donors from the donor population and by an increase in the number of return donors. Study of first time donor prevalences for HTLV-1/2 may provide a more accurate picture of the incidence of this infection in the blood donor pool.

\section{ACKNOWLEDGMENTS}

The authors would like to thank Cissa Soares for editing and reviewing the language.

\section{CONFLICT OF INTEREST}

The authors declare that there are no conflicts of interest.

\section{FINANCIAL SUPPORT}

This work was supported by the Fundação de Ensino e Pesquisa de Minas Gerais (FAPEMIG), the Fundação Hemominas and the Conselho Nacional de Desenvolvimento Científico e Tecnológico (CNPq). 


\section{REFERENCES}

1. Proietti FA, Carneiro-Proietti AB, Catalan-Soares B, Murphy E. Global Epidemiology of HTLV-1 infection and associated diseases. Oncogene $2005 ; 24: 6058-6068$.

2. Catalan-Soares B, Carneiro-Proietti AB, Proietti FA, Grupo Interdisciplinar de Pesquisas em HTLV. Heterogeneous geographical distribution of Human T Cell lymphothropic viruses I and II (HTLV-I/ II): serological screening prevalence rates in blood donors from large urban areas in Brazil. Cad Saude Publica 2005; 21:926-931.

3. Carneiro-Proietti ABF, Martins ML, Proietti FA. Grupo Interdisciplinar de Pesquisas em HTLV (GIPH) 1997-2007. Rev Fundação Ezequiel Dias 2007; 1:51-61.

4. Mota A, Nunes C, Melo A, Romeo M, Boasorte N, Dourado I, et al. A casecontrol study of HTLV-infection among blood donors in Salvador, Bahia, Brazil - Associated risk factors and trend towards declining prevalence. Rev Bras Hematol 2006; 28:120-126.

5. Galvão-Castro B, Loures L, Rodrigues LGM, Sereno A, Ferreira Jr OC, Franco LGP, et al. Distribution of Human Lymphotropic virus type 1 among blood donors: a nationwide Brazilian study. Transfusion 1997; 37:242-243.

6. Glynn AS, Kleinmam SH, Schreiber GB, Busch MP, Wright DJ, Smith JW, et al. Trends in Incidence and Prevalence of Major Transfusion-Transmissible Viral Infections in US Blood Donors, 1991-1996. J Am Med Assoc 2000; 284:229-235.

7. Fang CT, Williams AE, Sandler SG, Slamon DJ, Poiesz BJ. Detection of antibodies to human T-lymphotropic virus type I (HTLV-I). Transfusion 1988; 28:179183.

8. Williams AE, Fang CT, Slamon DJ, Poiesz BJ, Sandler SG, Darr Jr WF, et al. Seroprevalence and epidemiological correlates of HTLV-I infection in U.S. blood donors. Science 1988; 240:643-646.

9. Chiavetta JA, Escobar M, Newman A, He Y, Driezen P, Deeks S, et al. Incidence and estimated rates of residual risk for HIV, hepatitis C, hepatitis B and human T-cell lymphotropic viruses in blood donors in Canada, 1990-2000. Can Med Assoc J 2003; 169:767-773.

10. Stigum H, Magnus P, Samdal HH, Nord E. Human T-cell lymphotropic virus testing of blood donors in Norway, a cost-effect model. Int J Epidemiol 2000; 29:1076-1084

11. Tseliou PM, Spanakis N, Spiliotakara A, Politis C, Legakis NJ, Tsakris A HTLV-I and -II in southwestern Greece Transfusion 2003; 43:1641-1642.

12. Calattini S, Chevalier SA, Duprez R, Bassot S, Froment A, Mahieux R, et al. Discovery of a new human T-cell lymphotropic virus (HTLV-3) in Central Africa. Retrovirology 2005; 2:31-34

13. Carvalho SMF, Pombo-de-Oliveira MS, Thuler LCS, Leite NP, Santos AO, Nogueira RMP, et al. Cross-reactivity between Human T-cell LeukemiaLymphoma Virus indeterminate Western Blot and Dengue Virus in individuals from Rio de Janeiro, Brazil. J Acquir Immune Defic Syndr Human Retrovirol 1999; 20:4.

14. Santos TJ, Costa CM, Goubau P, Vandamme AM, Desmyter J, Van Doren S, et al. Western blot seroindeterminate individuals for human T-lymphotropic virus I/ II (HTLV-I/II) in Fortaleza (Brazil): a serological and molecular diagnostic and epidemiological approach. Braz J Infect Dis 2003; 7:202-209.

15. Tsao KC, Chen W, Huang CG, Huang YL, Lin JY, Mok CK, et al. False positive antibody results against human T-cell lymphotropic virus in patients with severe acute respiratory syndrome. J Med Virol 2005; 77:331-336.

16. Mahieux R, Horal P, Mauclère P, Mercereau-Puijalon O, Guillotte M, Meertens $\mathrm{L}$, et al. Human T-cell lymphotropic virus type $1 \mathrm{gag}$ indeterminate western blot patterns in Central Africa: relationship to Plasmodium falciparum infection. J Clin Microbiol 200; 38:4049-4057.

17. Mangano AM, Remesar M, del Pozo A, Sen L. Human T lymphotropic virus types I and II proviral sequences in Argentinian blood donors with indeterminate Western blot patterns. J Med Virol 2004; 74:323-327.

18. Síntese de Indicadores Sociais [Internet]. Brasília: Instituto Brasileiro de Geografia e Estatística. 2007 - [cited 2009 Aug]. Available from: ftp://ftp.ibge.gov. br/Indicadores_Sociais/Sintese_de_Indicadores_Sociais_2007/Tabelas/.
19. Carneiro-Proietti ABF, Ribas JGR, Catalan-Soares BC, Martins ML Brito-Melo GEA, Martins-Filho OA, et al. Infecção e doença pelos vírus linfotrópicos humanos de células T (HTLV-I/II) no Brasil. Rev Soc Bras Med Trop 2002; 35:499-508.

20. Murphy EL, Figueroa JP, Gibbs WN, Holding-Cobham M, Cranston B, Malley K et al. Human T-lymphotropic virus type I (HTLV-I) seroprevalence in Jamaica I. Demographic determinants. Am J Epidemiol 1991; 133:1114-1124. 